\title{
Impacts of the 2019-2020 Bushfires on New South Wales Biodiversity: A Rapid Assessment of Distribution Data for Selected Invertebrate Taxa
}

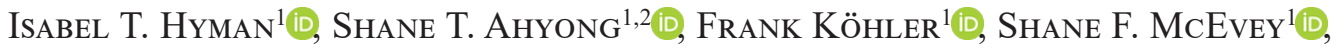 \\ Graham Milledge ${ }^{1}$ iD, Chris A. M. $\operatorname{ReID}^{1}$ (iD, Jodi J. L. Rowley ${ }^{1,2}$ (iD) \\ ${ }^{1}$ Australian Museum Research Institute, Australian Museum, 1 William St, Sydney NSW 2010, Australia \\ ${ }^{2}$ School of Biological, Earth and Environmental Sciences, \\ University of New South Wales, Kensington, NSW 2052, Australia
}

\begin{abstract}
We analyse expert-confirmed occurrence records from the collection of the Australian Museum of altogether 733 species of invertebrates that exhibit a wide range of life history strategies, dispersal abilities and ecological adaptations (dung beetles, spiny freshwater crayfishes, drosophilid flies, land snails, mygalomorph and archaeid spiders). For 29 species (two dung beetles, four species of spiny freshwater crayfishes, four drosophilid flies, 11 land snails, five mygalomorph and three archaeid spiders), all known occurrences are within the extent of the 2019-2020 bushfires. In addition, the ranges of another 46 species had at least half of their known occurrences completely contained within the fire zone. Given these figures, the conservation status of many NSW species may require revision to recognize the higher level of threat, and active conservation actions will need to be taken to ensure the survival of these and other species.
\end{abstract}

\section{Introduction}

The bushfires that impacted vast areas of eastern Australia from October 2019 to February 2020 were extensive and severe. In New South Wales (NSW) approximately 5.3 million hectares were burnt ( $7 \%$ of the state), including 2.7 million hectares of the state's National Parks (NSW State Government, Department of Planning, Industry and Environment [DPIE], 2020), affecting World Heritage areas such as the Greater Blue Mountains Area and the Gondwana Rainforests of Australia. Fifty-seven national parks and reserves had more than $99 \%$ of their area impacted by fire. The most affected ecosystems were rainforests $(35 \%$ of their state-wide extent), wet sclerophyll forests (41\%) and heathlands (53\%) (DPIE, 2020). Gondwanan rainforest is not a fire-adapted habitat, with tree-destroying fires only likely to occur at intervals of over 1000 years (Turner, 1984), making this habitat type and the species relying on it extremely vulnerable to fire damage. This habitat type is also likely to recover slowly.
The sheer scale of burnt areas has raised conservation concerns for many species that occur within the impact zone of these fires. Much emphasis has been put on the effects of the bushfires on iconic species such as the koala-Phascolarctos cinereus (Goldfuss, 1817) —of which an estimated 6382 individuals (or 15\% of NSW's koala population) may have perished in these fires (Lane et al., 2020). Seventy vertebrate species have also been identified as of particular conservation concern since more than $30 \%$ of their known distributions were burnt (Ward et al., 2020). Although equally relevant, the conservation impact on lesser-known species is generally poorly understood. We consider any animal species that has a comparatively narrow distribution in eastern Australia and has limited mobility in any of its life stages to be of particular concern.

Almost 1000 plant and animal species are formally listed as threatened under the NSW Biodiversity Conservation Act (2016), and the vast majority of these (estimated 973 species; DPIE, 2020) have at least parts of their distribution within the burnt areas. However, the listed species form only a fraction 
of the total number of species in NSW, an unknown figure that lacks even a reliable estimate. For comparison, there are an estimated 566,398 plant and animal species Australia-wide (Chapman, 2009).

Invertebrates, which according to estimates of Australia's biodiversity make up over $97 \%$ of all animal species (Chapman, 2009), play a critical role in ecosystem health and functioning but are generally under-represented in threatened species lists (Taylor et al., 2018). Many invertebrates are narrow-range endemics, increasing their vulnerability to widespread fires. Leaf litter-dwelling species are also known to be particularly vulnerable to bushfires (Buckingham et al., 2019). Many invertebrates are particularly diverse in moist, humid environments such as rainforest, which make up just $3 \%$ of the state's forests (ABARES, 2019) but are likely to contain a significant portion of its biodiversity (for example, rainforests make up $2.6 \%$ of Australia's forests but contain $60 \%$ of all plant species, $60 \%$ of butterfly species, $40 \%$ of bird species and $35 \%$ of mammal species-ABARES, 2019).

After severe bushfires, invertebrate diversity and abundance is reduced (Buckingham et al., 2019). In addition, there are changes to species composition after fires, with a higher proportion of larger invertebrates remaining, as smaller invertebrates may struggle to re-colonize burnt areas due to low vagility and/or greater susceptibility to desiccation under drier conditions (Buckingham et al., 2019). Studies of land snails have shown that snails living in burnt areas have higher mortality than in unburnt areas, indicating that survivors or re-colonizers of burnt areas may struggle to survive (Ray \& Bergey, 2015). Rapid weed growth after fires has a negative effect on invertebrates, and also makes these areas more susceptible to future fires (Sands, 2018). The loss of detritivores can result in an increased depth of dry leaf litter, increasing fuel load and also adding to the risk of further fires. Many invertebrates are negatively affected by current fire management regimes (Ray \& Bergey, 2015; Sands, 2018), with a need for fuel reduction burning to follow a micromosaic patch pattern in order to avoid the loss of overall invertebrate biodiversity (New et al., 2010; Sands, 2018).

The expansive and near simultaneous extent of the NSW bushfires also highlights the potentially underestimated significance of bushfires in assessments of conservation status. If the current NSW fire map (shown in Fig. 1) is correct, numerous native NSW species can be inferred to have been severely impacted, and possibly even made extinct. Therefore, in the immediate term, field surveys must be prioritized to ground truth the extent and granularity of the current NSW fire maps in order to more accurately assess the impacts on these species and inform conservation actions.

In order to strengthen the knowledge base about the potential impacts of these bushfires on the Australian biota, and to better understand future challenges in land management in light of recent events, we have undertaken a preliminary assessment of the potential scale of impacts of these fires on selected groups of invertebrates. Rapid responses are critical in order to manage and direct conservation efforts to the groups in greatest need. These assessments are based on the research collections of the Australian Museum (AM), the single largest repository of biodiversity data in NSW. These collections, and the information that they contain, can play an important role in reconstructing species distributions as well as in detecting changes in distributions over time for a wide range of taxa, from insects to mammals. We analysed the occurrence records for selected groups of invertebrates, whose taxonomy is relatively well-known and whose collections are well-curated, in order to estimate the impact of recent bushfires on the populations of a large number of species that represent different trophic levels and ecological adaptations.

\section{Methods}

The model groups used were chosen based on four criteria: (a) well-resolved taxonomy; (b) the group should be wellrepresented by already databased and expert-identified material in the collections of the AM; (c) the museum records should be considered comprehensive in their geographic coverage in order to best represent the distribution of the group; and (d) the taxa chosen should represent a variety of ecological adaptations and trophic levels, and have low vagility in at least one of their life stages. Based on these criteria, six model groups were chosen: dung beetles, spiny freshwater crayfishes (Euastacus), drosophilid flies, land snails, mygalomorph spiders and archaeid spiders.

For each group, all NSW records (excluding Lord Howe Island and Norfolk Island) from the AM were checked by a taxonomic specialist for each model taxon. Undescribed species were, in most cases, deleted, since these species are generally not well-known and their taxonomy is poorly understood. Imprecise records with large errors in coordinates $(>10 \mathrm{~km})$ were also deleted, as were records with obvious errors in taxonomy or occurrence. Duplicate records (with identical coordinates) were removed to avoid skewing the results based on multiple records at a single site. We also investigated the effect of limiting records to the past 50 years (1970-2020), in order to best reflect the current distribution. Some selected species were not limited to NSW. The final datasets used for analysis are published separately by Ahyong (2020), Köhler \& Hyman (2020), McEvey (2020a), Milledge (2020), and Reid (2020).

All statistical analyses were conducted in $\mathrm{R}$ ver. 3.6.2 ( $\mathrm{R}$ Core Team, 2019). We used two different sources of data on the Australian fires. The NSW Bushfire map (Fig. 1) indicated whether or not the site had burnt, and the Google Earth Engine Burnt Area Map (GEEBAM, 2020) indicated the impact of the fire on vegetation. For each taxonomic dataset we removed records with latitude or longitude values of zero and filtered records to the state of NSW (GADM database www.gadm.org, version 2.5, July 2015). We then assigned each record with each fire layer, allowing determination of the mapped burn status of each record. Species with ranges outside NSW were included, but are discussed individually under the sections for each taxon in the Discussion.

\section{Results}

From a total of 733 species studied, more than half (399 species) had some parts of their range contained within the fire zone. For 174 species, at least $25 \%$ of their known occurrence was in the fire zone; for 75 of these species, at least half of their known occurrence was in the fire zone; 36 species had $75 \%$ of their known occurrence burnt; and for 29 species their entire known range was burnt (see Table 1).

From a total of 92 dung beetle species, 54 were impacted by the bushfires and two species had their known ranges entirely contained within the fire zone (Fig. 2A; Tables 1,2). Most of these impacted species are flightless or restricted to wetter forests. For the two most heavily impacted species, $75-100 \%$ of the burnt sites were in the high to very high GEEBAM categories (Fig. 3A, Table 3).

From a total of 38 species of spiny freshwater crayfishes, 21 species were impacted by the bushfires and for ten species, $50 \%$ of their ranges were burnt. Four species had their known ranges completely contained within the fire zone (Fig. 2B; Tables 1,2). For the four most heavily impacted species, 


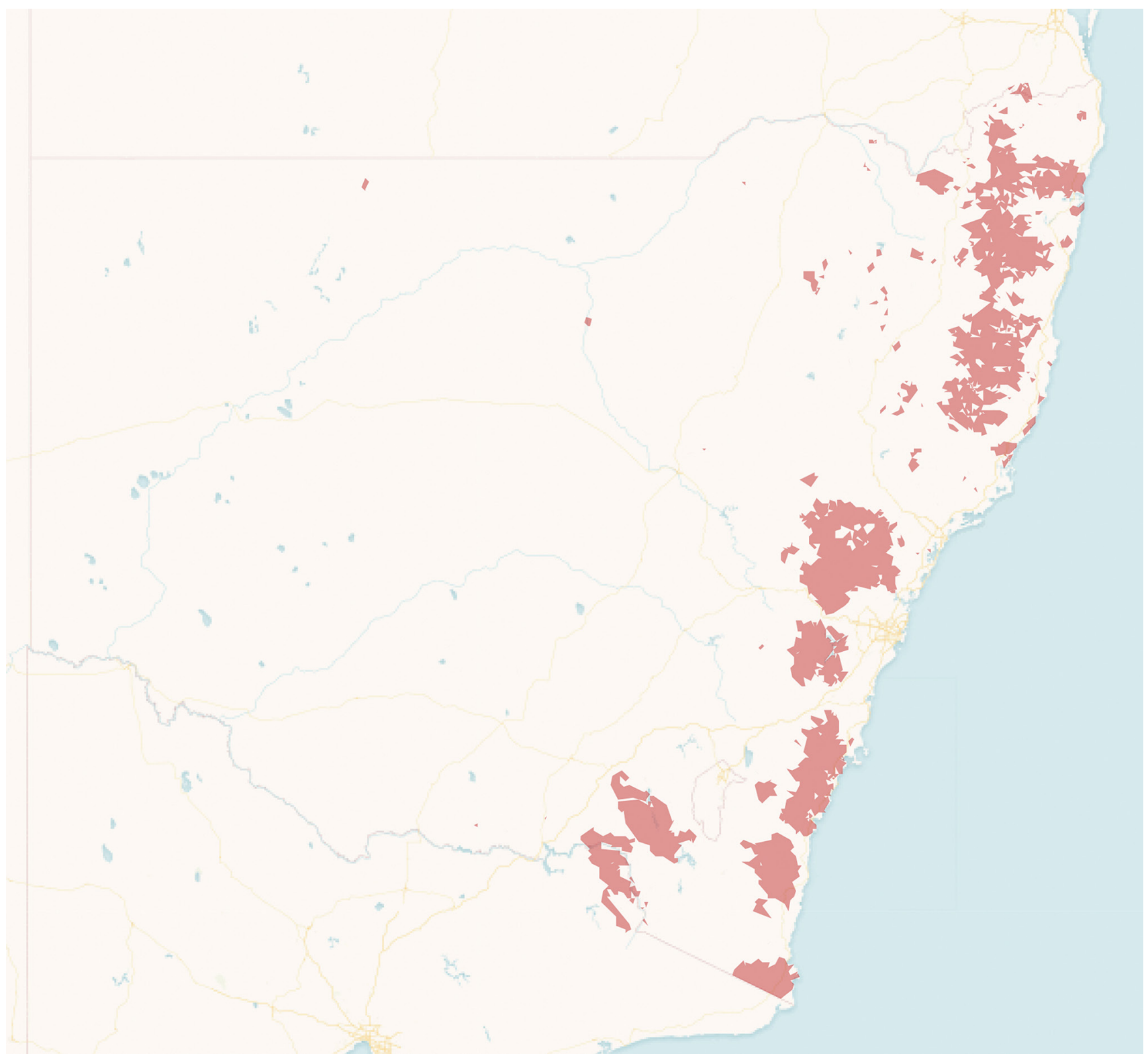

Figure 1. The NSW Bushfire map, showing areas that were burnt in the 2019-2020 bushfires. [Online source accessed April 2020] https://services9.arcgis.com/ZFIIzBMHgtglOEYj/arcgis/rest/services/NSW_Bushfire_Burnt_Areas_2019_and_2020/FeatureServer/0

$79-100 \%$ of the burnt sites were in the high to very high GEEBAM categories (Fig. 3B, Table 4).

From a total of 123 species of drosophilid flies, 75 were impacted by the bushfires and four species had their known ranges completely contained within the fire zone (Fig. 2C; Tables 1,2). For three of the four most heavily impacted species, $100 \%$ of the burnt sites were in the high to very high GEEBAM categories, while for the fourth, $100 \%$ of the burnt sites were in the low GEEBAM category (Fig. 3C, Table 5).

From a total of 341 species of land snails, 206 were impacted by the bushfires and 11 species had their known ranges completely contained within the fire zone (Fig. 2D; Tables 1,2). For one of the 11 most heavily impacted species, $100 \%$ of the burn sites were in the very high GEEBAM categories; for another four species $33-50 \%$ of the burn sites were in the high to very high GEEBAM categories; and for the last six species the burn sites were primarily in the low, medium or non-native GEEBAM categories (Fig. 3D, Table 6).

From a total of 126 species of mygalomorph spiders, 36 were impacted by the bushfires and five species had their known ranges completely contained within the fire zone (Fig. $2 \mathrm{E}$; Tables 1, 2). For two of the five most heavily impacted species, $100 \%$ of the burn sites were in the high GEEBAM category; for one species, $45 \%$ of the burn sites were in the very high GEEBAM category; while for the remaining two species $100 \%$ of the burn sites were in the low GEEBAM category (Fig. 3E, Table 7).

From a total of ten species of archaeid spiders, three were impacted by the bushfires, all having their known ranges completely contained within the fire zone (Fig. 2F; Tables 1, 2). 


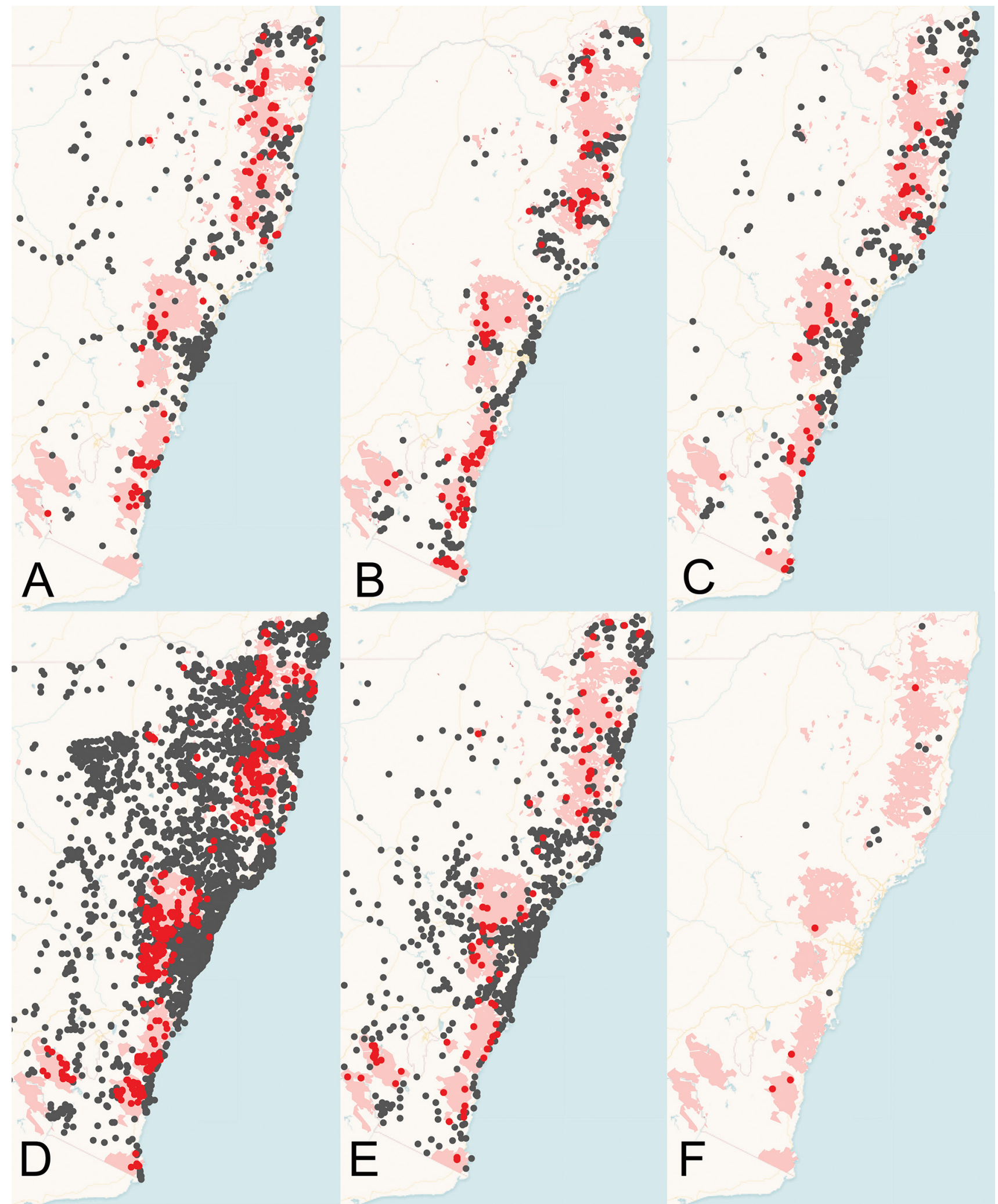

Figure 2. Mapped species records for each of the taxonomic groups, showing records from burnt sites in red and records from unburnt sites in black. The extent of the bushfires is marked in pink. (A) Dung beetles; (B) spiny freshwater crayfishes; $(C)$ drosophilid flies; (D) land snails; $(E)$ mygalomorph spiders; and $(F)$ archaeid spiders. 


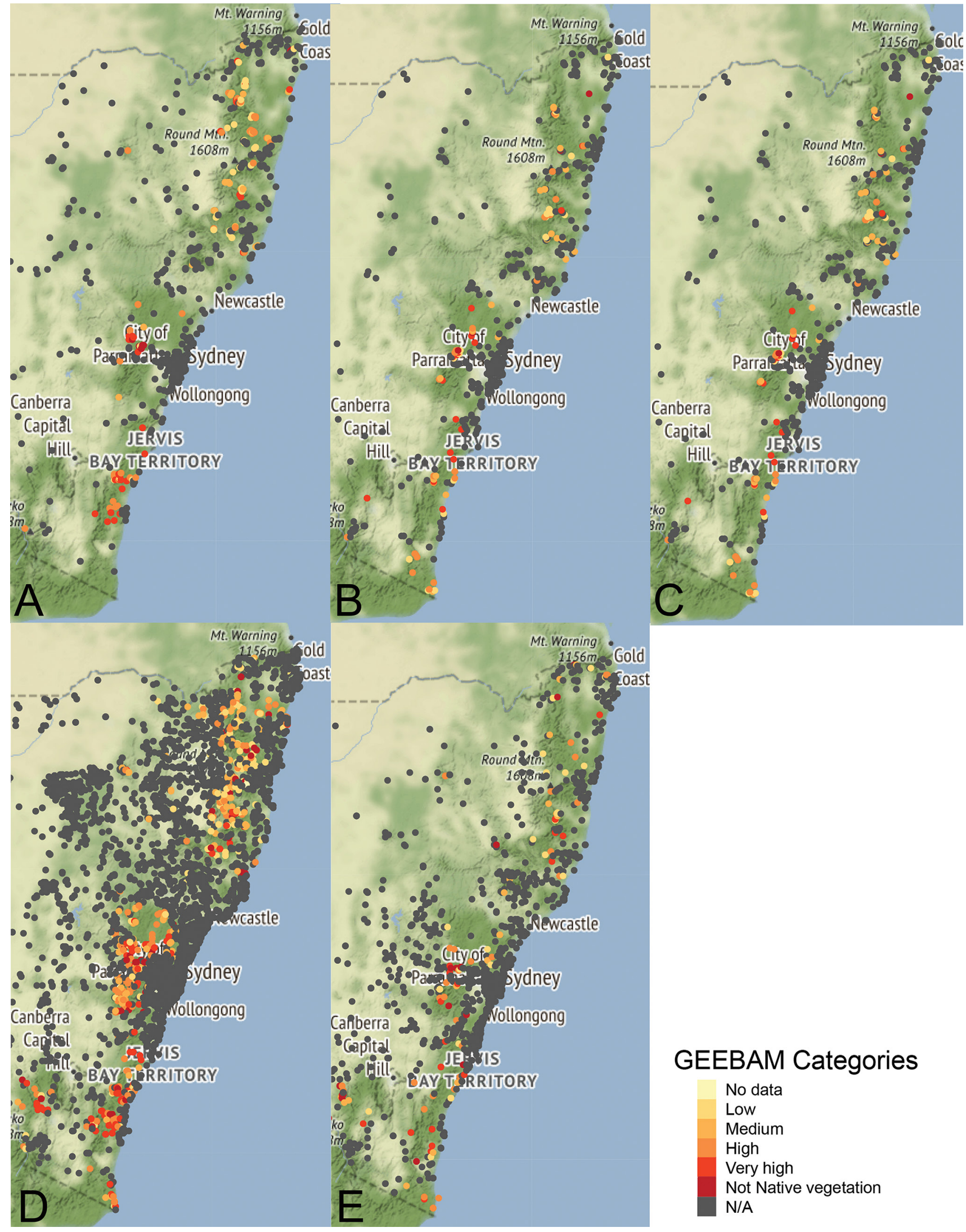

Figure 3. Mapped species records for each of the taxonomic groups, using the Google Earth Engine Burnt Area Map (GEEBAM) to show the impact of the fire on vegetation at each site. (A) Dung beetles; $(B)$ spiny freshwater crayfishes; $(C)$ drosophilid flies; $(D)$ land snails; and $(E)$ spiders. 
Table 1. Overall number of species and number of species affected by the bushfires in each taxonomic group. Duplicate records (with identical coordinates) have been removed. For each group (dung beetles, spiny freshwater crayfishes, drosophilid flies, land snails, and mygalomorph $(\mathrm{m})$ and archaeid $(a)$ spiders), all records are shown in the first column (all), and records for the last 50 years (1970 to 2020) are shown in the second column (1970).

\begin{tabular}{llllllllllllllll}
\hline & \multicolumn{1}{c}{ beetles } & \multicolumn{2}{c}{ crayfishes } & \multicolumn{2}{c}{ flies } & \multicolumn{2}{c}{ snails } & \multicolumn{2}{c}{ spiders (m) } & spiders (a) & total \\
\hline & all & 1970 & all & 1970 & all & 1970 & all & 1970 & all & 1970 & all & 1970 & all & 1970 \\
\hline number of species & 95 & 94 & 38 & 37 & 123 & 119 & 341 & 329 & 126 & 116 & 10 & 10 & 733 & 705 \\
species with any habitat burned & 57 & 55 & 21 & 20 & 75 & 71 & 206 & 201 & 36 & 34 & 3 & 3 & 398 & 384 \\
species with at least 25\% burned & 32 & 32 & 12 & 13 & 23 & 28 & 88 & 105 & 16 & 14 & 3 & 3 & 174 & 195 \\
species with at least 50\% burned & 15 & 15 & 9 & 9 & 8 & 9 & 28 & 37 & 12 & 10 & 3 & 3 & 75 & 83 \\
species with at least 75\% burned & 5 & 6 & 5 & 5 & 5 & 5 & 13 & 15 & 5 & 6 & 3 & 3 & 36 & 40 \\
species with 100\% burned & 2 & 3 & 4 & 4 & 4 & 4 & 11 & 12 & 5 & 6 & 3 & 3 & 29 & 32 \\
\hline
\end{tabular}

Table 2. A list of species that had $25 \%$ or more of their known occurrence burnt in the 2019-2020 bushfires. Species identified in the current study as priority species for immediate conservation management are marked with a hash symbol (\#); while species similarly identified in two recent Australian Government reports (DAWE, 2020a; Legge et al., 2020) are marked with an asterisk $(*)$.

\begin{tabular}{|c|c|c|}
\hline \multicolumn{2}{|c|}{ Species with $100 \%$ of their known occurrences burnt } & \multirow{2}{*}{$\begin{array}{l}\% \text { burnt } \\
100 \%\end{array}$} \\
\hline beetles & Onthophagus weringerong Storey \& Weir, 1990 & \\
\hline & Thyregis kershawi Blackburn, 1904 & $100 \%$ \\
\hline \multirow[t]{4}{*}{ crayfishes } & Euastacus bidawalus Morgan, 1986 * & $100 \%$ \\
\hline & Euastacus guwinus Morgan, 1997 *\# & $100 \%$ \\
\hline & Eustacus "spinifer" \# & $100 \%$ \\
\hline & Euastacus vesper McCormack \& Ahyong, 2017 \# & $100 \%$ \\
\hline \multirow[t]{4}{*}{ flies } & Acletoxenus formosus (Leow, 1864) & $100 \%$ \\
\hline & Leucophenga subpollinosa Huang, Su \& Chen, 2017 & $100 \%$ \\
\hline & Scaptodrosophila eluta (Wheeler \& Takada, 1964) & $100 \%$ \\
\hline & Scaptodrosophila jackeyi (Bock, 1982) & $100 \%$ \\
\hline \multirow[t]{11}{*}{ snails } & Austrochloritis kippara Stanisic, 2010 *\# & $100 \%$ \\
\hline & Coricudgia wollemiana Stanisic, 2005 *\# & $100 \%$ \\
\hline & Egilodonta bendethera Stanisic, 2005 *\# & $100 \%$ \\
\hline & Egilomen sebastopol Stanisic, $2010 * \#$ & $100 \%$ \\
\hline & Gyrocochlea janetwaterhouseae Shea, Colgan \& Stanisic 2012 *\# & $100 \%$ \\
\hline & Hedleyropa yarrangobillyensis Stanisic, 2005 *\# & $100 \%$ \\
\hline & Letomola lanalittleae Stanisic, $2005 * \#$ & $100 \%$ \\
\hline & Macrophallikoropa stenoumbilicata Stanisic, 2005 *\# & $100 \%$ \\
\hline & Planorbacochlea dandahra Shea, Colgan \& Stanisic 2012 \# & $100 \%$ \\
\hline & Rhophodon palethorpei Stanisic, $2005 * \#$ & $100 \%$ \\
\hline & Sigaloeista gracilis Köhler, 2019 \# & $100 \%$ \\
\hline \multirow[t]{8}{*}{ spiders } & Aname caeruleomontana Raven, 1984 \# & $100 \%$ \\
\hline & Arbanitis helensmithae (Wishart \& Rowell, 2008) \# & $100 \%$ \\
\hline & Arbanitis horsemanae (Wishart, 2011) \# & $100 \%$ \\
\hline & Arbanitis macei (Wishart \& Rowell, 2008) \# & $100 \%$ \\
\hline & Carrai afoveolata Raven, 1984 \# & $100 \%$ \\
\hline & Austrarchaea mcguiganae Rix \& Harvey, 2011 \# & $100 \%$ \\
\hline & Austrarchaea monteithi Rix \& Harvey, 2011 \# & $100 \%$ \\
\hline & Austrarchaea smithae Rix \& Harvey, 2011 \# & $100 \%$ \\
\hline
\end{tabular}

\begin{tabular}{lll} 
Species with 75-99\% of their known occurrences burnt & $92 \%$ \\
beetles & Matthewsius illawarrensis Matthews, 1974 *\# & $75 \%$ \\
& Onthophagus squalidus Lea, 1923 & $75 \%$ \\
crayfishes & Matthewsius rossi (Matthews, 1974) *\# & $80 \%$ \\
flies & Euastacus clarkae Morgan, 1997 *\# & $80 \%$ \\
snails & Scaptodrosophila ehrmanae (Parsons \& Bock, 1977) \# & $78 \%$ \\
& Austrochloritis seaviewensis Stanisic \& Potter, 2010 *\# & $75 \%$ \\
\hline
\end{tabular}


Table 2 (continued)

\begin{tabular}{|c|c|c|}
\hline \multicolumn{3}{|c|}{ Species with $50-74 \%$ of their known occurrences burnt } \\
\hline \multirow[t]{10}{*}{ beetles } & Diorygopyx duplodentatus Matthews, 1974 *\# & $67 \%$ \\
\hline & Aulacopris reichei White, $1859 *$ & $60 \%$ \\
\hline & Onthophagus msp cbcr3-001 \# & $60 \%$ \\
\hline & Amphistomus trispiculatus Matthews, 1974 & $59 \%$ \\
\hline & Onthophagus rubicundulus Macleay, 1871 & $58 \%$ \\
\hline & Aulacopris maximus Matthews, 1974 & $52 \%$ \\
\hline & Lepanus msp NSW-2 & $50 \%$ \\
\hline & Lepanus nr pisoniae Lea, $1923 *$ & $50 \%$ \\
\hline & Lepanus ustulatus (Lansberg, 1874) & $50 \%$ \\
\hline & Onthophagus kokereka Matthews, 1972 & $50 \%$ \\
\hline \multirow[t]{4}{*}{ crayfishes } & Euastacus pilosus Coughran \& Leckie, 2007 *\# & $73 \%$ \\
\hline & Euastacus girurmulayn Coughran, $2005 * \#$ & $67 \%$ \\
\hline & Euastacus yanga Morgan, 1997 \# & $61 \%$ \\
\hline & Euastacus claytoni Riek, 1969 \# & $50 \%$ \\
\hline \multirow[t]{3}{*}{ flies } & Leucophenga domanda Bock, 1984 & $50 \%$ \\
\hline & Scaptodrosophila anthemon (Bock, 1976) & $50 \%$ \\
\hline & Scaptodrosophila insolita (Bock, 1976) \# & $50 \%$ \\
\hline \multirow[t]{15}{*}{ snails } & Austrochloritis wollemiensis Shea \& Griffiths, 2010 *\# & $71 \%$ \\
\hline & Vitellidelos kaputarensis Shea \& Griffiths, 2010 *\# & $71 \%$ \\
\hline & Gyrocochlea gibraltar Stanisic, 2010 *\# & $67 \%$ \\
\hline & Meredithena marysvillensis (Gabriel, 1947) \# & $67 \%$ \\
\hline & Protorugosa alpica (Iredale, 1943) \# & $67 \%$ \\
\hline & Austrochloritis kaputarensis Stanisic, 2010 *\# & $60 \%$ \\
\hline & Prolesophanta occlusa Shea \& Griffiths, 2010 \# & $57 \%$ \\
\hline & Austrochloritis abrotonus Shea \& Griffiths, 2010 *\# & $56 \%$ \\
\hline & Pommerhelix monacha (Pfeiffer, 1859) *\# & $55 \%$ \\
\hline & Oreomava cannfluviatilus (Gabriel, 1929) \# & $53 \%$ \\
\hline & Austrochloritis paucisetosa Stanisic, 2010 *\# & $50 \%$ \\
\hline & Kandoschloritis pustulosus Shea \& Griffiths, 2010 \# & $50 \%$ \\
\hline & Macleayropa boonanghi Stanisic, 2010 *\# & $50 \%$ \\
\hline & Planorbacochlea manningensis Shea, Colgan \& Stanisic, 2012 \# & $50 \%$ \\
\hline & Rhophodon kempseyensis Stanisic, 2005 *\# & $50 \%$ \\
\hline \multirow[t]{7}{*}{ spiders } & Ixamatus fischeri Raven, 1982 \# & $67 \%$ \\
\hline & Paraembolides boydi (Raven, 1978) \# & $67 \%$ \\
\hline & Arbanitis paulaskewi (Wishart, 2011) \# & $50 \%$ \\
\hline & Cethegus barraba Raven, 1984 \# & $50 \%$ \\
\hline & Hadronyche emmalizae Gray, 2010 \# & $50 \%$ \\
\hline & Ixamatus musgravei Raven, 1982 \# & $50 \%$ \\
\hline & Atrax yorkmainorum Gray, 2010 \# & $50 \%$ \\
\hline \multicolumn{3}{|c|}{ Species with $25-49 \%$ of their known occurrences burnt } \\
\hline \multirow[t]{17}{*}{ beetles } & Diorygopyx niger Matthews, 1974 & $43 \%$ \\
\hline & Amphistomus speculifer Matthews, 1974 & $42 \%$ \\
\hline & Diorygopyx incrassatus Matthews, $1974 *$ & $40 \%$ \\
\hline & Onthophagus kiambram Storey, 1977 & $40 \%$ \\
\hline & Diorygopyx incomptus Matthews, 1974 & $36 \%$ \\
\hline & Lepanus bidentatus (Wilson, 1922) & $36 \%$ \\
\hline & Cephalodesmius armiger Westwood, 1842 & $34 \%$ \\
\hline & Diorygopyx tibialis (Macleay, 1871) & $33 \%$ \\
\hline & Onthophagus hoplocerus Lea, 1923 & $33 \%$ \\
\hline & Onthophagus tweedensis Blackburn, 1903 & $33 \%$ \\
\hline & Onthophagus yourula Storey \& Weir, 1990 & $33 \%$ \\
\hline & Onthophagus blackburni Shipp, 1895 & $30 \%$ \\
\hline & Diorygopyx simpliciclunis Matthews, 1974 & $29 \%$ \\
\hline & Onthophagus longipes Paulian, 1937 & $29 \%$ \\
\hline & Onthophagus pugnax Harold, 1868 & $29 \%$ \\
\hline & Onthophagus incornutus Macleay, 1871 & $25 \%$ \\
\hline & Onthophagus nurubuan Matthews, 1972 & $25 \%$ \\
\hline
\end{tabular}


Table 2 (continued).

\begin{tabular}{|c|c|c|}
\hline \multicolumn{2}{|c|}{ Species with $25-49 \%$ of their known occurrences burnt (continued) } & \multirow{2}{*}{$\begin{array}{l}\% \text { burnt } \\
38 \%\end{array}$} \\
\hline \multirow[t]{18}{*}{ crayfishes } & Euastacus suttoni Clark, 1941 * & \\
\hline & Euastacus simplex Riek, 1956 * & $31 \%$ \\
\hline & Euastacus spinichelatus Morgan, 1997 * & $30 \%$ \\
\hline & Microdrosophila discrepantia Bock, 1982 & $43 \%$ \\
\hline & Microdrosophila pleurolineata Wheeler \& Takada, 1964 & $40 \%$ \\
\hline & Scaptodrosophila novamaculosa (Mather, 1956) & $40 \%$ \\
\hline & Leucophenga cyanorosa Bock, 1979 \# & $38 \%$ \\
\hline & Scaptodrosophila garnetensis (Bock, 1984) & $36 \%$ \\
\hline & Mycodrosophila marksae Bock, 1980 & $33 \%$ \\
\hline & Scaptodrosophila rhabdote (Bock, 1976) & $33 \%$ \\
\hline & Scaptodrosophila collessi (Bock, 1976) & $32 \%$ \\
\hline & Scaptodrosophila minnamurrae (Bock, 1976) \# & $30 \%$ \\
\hline & Scaptodrosophila cancellata (Mather, 1955) & $29 \%$ \\
\hline & Scaptodrosophila megagenys (Bock, 1976) & $29 \%$ \\
\hline & Scaptodrosophila inornata (Malloch, 1923) & $28 \%$ \\
\hline & Hirtodrosophila donaldi (Wheeler, 1981) & $25 \%$ \\
\hline & Microdrosophila hasta Bock, 1982 & $25 \%$ \\
\hline & Scaptodrosophila vindicta (Parsons \& Bock in Bock, 1982) \# & $25 \%$ \\
\hline \multirow[t]{45}{*}{ snails } & Austrorhytida nandewarensis Shea \& Griffiths, $2010 *$ & $48 \%$ \\
\hline & Austrochloritis kanangra Shea \& Griffiths, $2010 *$ & $48 \%$ \\
\hline & Austrochloritis speculoris Shea \& Griffiths, 2010 & $47 \%$ \\
\hline & Pommerhelix mastersi (Cox, 1864) * & $47 \%$ \\
\hline & Austrorhytida harriettae (Cox, 1868) & $46 \%$ \\
\hline & Annabellia assimilans (Cox, 1864) & $44 \%$ \\
\hline & Sigaloeista rubra Stanisic, 2010 & $44 \%$ \\
\hline & Vitellidelos dorrigoensis Shea \& Griffiths, $2010 *$ & $44 \%$ \\
\hline & Diphyoropa macleayana Stanisic, $2005 *$ & $43 \%$ \\
\hline & Macrophallikoropa depressispira Stanisic, $2005 *$ & $43 \%$ \\
\hline & Terrycarlessia turbinata Stanisic, 2010 & $41 \%$ \\
\hline & Pommerhelix depressa (Hedley, 1901) * & $41 \%$ \\
\hline & Elsothera grossa Stanisic, 2010 & $41 \%$ \\
\hline & Nitor wiangariensis Hyman, 2007 & $40 \%$ \\
\hline & Planorbacochlea reticulata Shea, Colgan \& Stanisic, 2012 & $40 \%$ \\
\hline & Sigaloeista dorrigo Köhler, 2019 & $40 \%$ \\
\hline & Helicarion cuvieri Férussac, 1821 & $38 \%$ \\
\hline & Brevisentis kaputarensis Shea \& Griffiths, $2010 *$ & $38 \%$ \\
\hline & Montidelos macquariensis (Cox, 1872) & $38 \%$ \\
\hline & Paralaoma annabelli Shea \& Griffiths, $2010 *$ & $38 \%$ \\
\hline & Comboynea conferta (Hedley, 1924) & $37 \%$ \\
\hline & Egilodonta bairnsdalensis (Gabriel, 1930) & $36 \%$ \\
\hline & Cystopelta astra Iredale, 1937 & $36 \%$ \\
\hline & Meridolum jervisensis (Quoy \& Gaimard, 1832) * & $35 \%$ \\
\hline & Parmavitrina megastoma (Cox, 1868) & $35 \%$ \\
\hline & Coenocharopa multiradiata Stanisic, 1990 & $34 \%$ \\
\hline & Austrochloritis abbotti Stanisic, 2010 & $33 \%$ \\
\hline & Cralopa kaputarensis Stanisic, 1990 & $33 \%$ \\
\hline & Excellaoma retipora $(\mathrm{Cox}, 1867)$ & $33 \%$ \\
\hline & Gyrocochlea notiala Stanisic, 2010 & $33 \%$ \\
\hline & Macleayropa carraiensis Stanisic, $2010 *$ & $33 \%$ \\
\hline & Scelidoropa nandewar Stanisic, $2005 *$ & $33 \%$ \\
\hline & Austrochloritis nambucca Iredale, 1943 & $33 \%$ \\
\hline & Brazieresta larreyi (Brazier, 1871) & $32 \%$ \\
\hline & Ponderconcha gilberti (Pfeiffer, 1846) & $32 \%$ \\
\hline & Pupisoma evada (Iredale, 1944) & $31 \%$ \\
\hline & Planorbacochlea yessabahensis Shea, Colgan \& Stanisic, 2012 & $31 \%$ \\
\hline & Pommerhelix exocarpi (Cox, 1868) & $30 \%$ \\
\hline & Austrochloritis stanisici Shea \& Griffiths, 2010 & $30 \%$ \\
\hline & Diphyoropa illustra (Gabriel, 1947) * & $30 \%$ \\
\hline & Austrorhytida glaciamans (Iredale, 1938) * & $30 \%$ \\
\hline & Scelidoropa sarahjaneae Stanisic, 2005 & $29 \%$ \\
\hline & Flammulops excelsior (Hedley, 1896) & $29 \%$ \\
\hline & Tarocystis glenrockensis (Hyman, 2007) & $28 \%$ \\
\hline & Elsothera kyliestumkatae Stanisic, 2010 * & $27 \%$ \\
\hline
\end{tabular}


Table 2 (continued).

\begin{tabular}{|c|c|c|}
\hline \multicolumn{2}{|c|}{ Species with $25-49 \%$ of their known occurrences burnt (continued) } & \multirow{2}{*}{$\begin{array}{l}\% \text { burnt } \\
27 \%\end{array}$} \\
\hline & Meridistes woolnoughi Stanisic, 2010 & \\
\hline & Austrochloritis kosciuszkoensis Shea \& Griffiths, 2010 * & $27 \%$ \\
\hline & Atopos australis (Heynemann, 1876) & $27 \%$ \\
\hline & Pseudiotula eurysiana Stanisic, 2010 & $26 \%$ \\
\hline & Mysticarion porrectus (Iredale, 1941) * & $25 \%$ \\
\hline & Helicarion mastersi (Cox, 1868) & $25 \%$ \\
\hline & Dictyoropa eurythma (Hedley, 1924) & $25 \%$ \\
\hline & Gyrocochlea hawkesburyana Stanisic, 2010 & $25 \%$ \\
\hline & Pommerhelix duralensis (Cox, 1868) & $25 \%$ \\
\hline & Montidelos exiguus Shea \& Griffiths, 2010 & $25 \%$ \\
\hline & Mysticarion hyalinus (Pfeiffer, 1855) & $25 \%$ \\
\hline & Omegapilla australis (Angas, 1864) & $25 \%$ \\
\hline & Ventopelita leucocheilus (Cox, 1868) & $25 \%$ \\
\hline & Triboniophorus graeffei Humbert, 1863 & $25 \%$ \\
\hline & Thersites novaehollandiae (Gray, 1834) & $25 \%$ \\
\hline \multirow[t]{4}{*}{ spiders } & Arbanitis mascordi (Wishart, 1992) & $40 \%$ \\
\hline & Hadronyche meridiana Hogg, 1901 & $40 \%$ \\
\hline & Atrax sutherlandi Gray, 2010 & $32 \%$ \\
\hline & Cataxia pulleinei (Rainbow, 1914) & $25 \%$ \\
\hline
\end{tabular}

\section{Discussion}

\section{General conservation implications}

The effects of the 2019-2020 bushfires on invertebrates are manifold. Primarily, the fires have caused the immediate deaths of a large, yet unquantifiable number of individuals (i.e., fire caused decreases in population size). Any species which has experienced a reversible population reduction of more than $50 \%$ due to a known threat that has ceased to exist (i.e., the 2019-2020 bushfires) is assessed as threatened according to IUCN Red List criterion A1 (IUCN, 2012). Our study revealed that $10.7 \%$ of all analysed species had $50 \%$ or more of their known occurrences burnt. If the proportion of affected occurrence records can be used as an estimator for the reduction in population size, these species may fall in one of the Red List Categories simply due to the immediate reduction in population size caused by the bushfires. Whether there is a correlation between proportion of burnt occurrences and reduction in population size is arguable and depends on the survival rates in burnt areas and the representativeness of the available distribution data.

The impacts of the bushfires, however, go beyond the immediate mortality of individuals in burnt areas. In addition, the bushfires are likely to cause increased mortality for some time after the fires have been extinguished due to the changed habitat conditions that burnt areas provide in comparison with unburnt sites (e.g., Ray \& Bergey, 2015). The bushfires have certainly caused at least the temporary loss of swathes of suitable habitat by converting close canopy forests with undergrowth and leaf litter that harbour an intricate ecosystem with complex species interactions, into more open and exposed landscapes that have lost parts of their former species inventory and provide new selective arenas. Such altered habitat structures may have cascading ecological impacts that may benefit the advent of competitors, predators, or invasive species at the detriment of indigenous species (Fahrig, 2003; Hewitt et al., 2005; Lawton et al., 1998; Sands, 2018). While these indirect impacts of bushfires are even harder to quantify, they are likely to cause medium to long-term reductions in the extent of occurrence (EOO), area of occupancy (AOO) and population trend of species, in addition to the above-mentioned population reduction. The combined effects are likely to trigger additional IUCN Red List criteria and have the potential to inflate the list of species that are eligible for a formal listing as threatened.

Thirdly, the direct and indirect impacts of bushfires are likely to exacerbate any pre-existing threats to native species and may accelerate any pre-existing declines in the extent of the distributional range of species and their genetic diversity as well as to promote population fragmentation.

The long-term effects of the 2019-2020 bushfires on species depend on a number of intrinsic variables, which require detailed assessments. As detailed single-species assessments are time consuming, it is prudent to prioritize those species for assessments that have large parts of their known distribution in burnt areas. Such species would be those with comparatively small ranges, comparatively low fecundity and/or dispersal ability, and species that inhabit habitats that normally do not experience bushfires, such as rainforests.

\section{Dung beetles}

There are at least 450 species of true dung beetle (Coleoptera: Scarabaeidae: Scarabaeinae) in Australia (Gunter et al., 2019) of which approximately 120 occur in NSW (Harris \& Reid, 2016; Gunter et al., 2019). In this discussion the introduced fauna (25 species; Edwards et al., 2015) is ignored, as it is exotic and entirely associated with open habitats, particularly pastures (Gollan et al., 2011). Overall the greatest diversity of native dung beetles in NSW is in more mesic habitats along the coastal side of the Great Dividing Range. However, the dung beetles of NSW are best considered as two groups, separated phylogenetically and generally also by habitat and vagility.

The genus Onthophagus includes about 70 species in NSW, all but one fully winged and active fliers, which are mostly widespread in distribution and in drier forests. Most species are generalists, feeding on a wide range of animal faeces but also rotting fungi and other mushy pabula (Matthews, 1972; Ebert et al., 2019). One species of Onthophagus, O. weringerong Storey \& Weir, 1990, was identified in our study as critically impacted by the fires, 
Table 3. The impact of the fire, measured using GEEBAM categories, on all dung beetle species that had $50 \%$ or more of their known occurrence burnt.

\begin{tabular}{|c|c|c|c|c|c|c|}
\hline & 2 & 3 & 4 & 5 & 6 & $4+5$ \\
\hline Beetles & low & medium & high & very high & $\begin{array}{l}\text { not native } \\
\text { vegetation }\end{array}$ & $\begin{array}{c}\text { total } \\
\text { high+very high }\end{array}$ \\
\hline Thyregis kershawi & $0 \%$ & $0 \%$ & $0 \%$ & $100 \%$ & $0 \%$ & $100 \%$ \\
\hline Matthewsius illawarrensis & $13 \%$ & $0 \%$ & $50 \%$ & $33 \%$ & $3 \%$ & $83 \%$ \\
\hline Lepanus $\mathrm{nr}$ pisoniae & $0 \%$ & $0 \%$ & $75 \%$ & $0 \%$ & $0 \%$ & $75 \%$ \\
\hline Onthophagus weringerong & $0 \%$ & $25 \%$ & $75 \%$ & $0 \%$ & $0 \%$ & $75 \%$ \\
\hline Diorygopyx duplodentatus & $0 \%$ & $0 \%$ & $33 \%$ & $33 \%$ & $0 \%$ & $67 \%$ \\
\hline Aulacopris reichei & $0 \%$ & $0 \%$ & $25 \%$ & $25 \%$ & $0 \%$ & $50 \%$ \\
\hline Matthewsius rossi & $0 \%$ & $0 \%$ & $0 \%$ & $50 \%$ & $14 \%$ & $50 \%$ \\
\hline Onthophagus squalidus & $20 \%$ & $20 \%$ & $40 \%$ & $0 \%$ & $0 \%$ & $40 \%$ \\
\hline Onthophagus msp cbcr3-001 & $0 \%$ & $0 \%$ & $25 \%$ & $13 \%$ & $0 \%$ & $38 \%$ \\
\hline Amphistomus trispiculatus & $41 \%$ & $2 \%$ & $16 \%$ & $10 \%$ & $2 \%$ & $25 \%$ \\
\hline Onthophagus rubicundulus & $21 \%$ & $0 \%$ & $21 \%$ & $0 \%$ & $0 \%$ & $21 \%$ \\
\hline Aulacopris maximus & $25 \%$ & $3 \%$ & $9 \%$ & $6 \%$ & $0 \%$ & $16 \%$ \\
\hline Lepanus msp NSW-2 & $29 \%$ & $5 \%$ & $5 \%$ & $6 \%$ & $0 \%$ & $11 \%$ \\
\hline Lepanus ustulatus & $67 \%$ & $0 \%$ & $0 \%$ & $0 \%$ & $0 \%$ & $0 \%$ \\
\hline Onthophagus kokereka & $0 \%$ & $20 \%$ & $0 \%$ & $0 \%$ & $0 \%$ & $0 \%$ \\
\hline
\end{tabular}

$50-74 \% \square 75-99 \% \square$ 100\% burnt

with $100 \%$ of the NSW range affected, and one species, O. squalidus Lea, 1923 had $75 \%$ of its range impacted. Three species, O. rubicundulus Macleay, 1871, O. kokoreka Matthews, 1972, and an undescribed species coded $O$. CBCR species 1 , had $50-60 \%$ of their ranges impacted. However, when compared with the Australian database of Scarabaeinae on the Atlas of Living Australia (Anonymous, 2020a), none of the described Onthophagus species noted above are restricted to NSW and so none can be considered threatened by the fires of 2019-2020, although their ranges may have been reduced. The only threatened species of Onthophagus is the most unusual, as it is the only flightless species of Onthophagus in Australia (O. CBCR species 1). This species is only known from eight specimens, all collected in 1993 from three wet forest sites within $100 \mathrm{~km}$ of each other, and it urgently needs to be formally described and registered as threatened.

The remaining native dung beetles include approximately 50 species in 10 relatively small genera (Matthews, 1974, 1976; Gunter et al., 2019). In contrast to Onthophagus, these are often flightless, generally restricted to mesic forests and have small ranges. Ten species were found to be impacted in at least $50 \%$ of their NSW ranges. Three are species of Lepanus, a genus in the process of being revised (Gunter \& Weir, 2019). For this reason they are not discussed further, except to note that L. ustulatus (Lansberge, 1874), with 50\% of its NSW range impacted, is a volant and common species in wetter forests of southeast Queensland. The remaining seven species are flightless. These species and the estimated ranges impacted in NSW are: Thyregis kershawi Blackburn, 1904 (100\%), Matthewsius illawarrensis (Matthews, 1974) (92\%), M. rossi (Matthews, 1974) (75\%), Diorygopyx duplodentatus Matthews, 1974 (67\%), Aulacopris reichei White, 1859 (60\%), A. maximus Matthews, 1974 (52\%) and Amphistomus trispiculatus Matthews, 1974 (59\%). Of these, four species also have several records in neighbouring states: T. kershawi is rare in NSW but common in central Victoria (Matthews, 1976; Anonymous, 2020a), A. reichei is widespread from central NSW to central Victoria (Matthews, 1974; Anonymous, 2020a), A. maximus occurs from central NSW to southeast Queensland (Matthews, 1974; Anonymous, 2020a) and $A$. trispiculatus is restricted to northeast NSW and southeast Queensland (Matthews, 1974; Anonymous, 2020a). Their populations in NSW may have been threatened but they appear to be secure elsewhere. Matthewsius illawarrensis and M. rossi are only known from three rainforest localities in and around the Sydney Basin area (Gunter \& Weir, 2017) and must be regarded as Critically Endangered (IUCN, 2012)by the impacts of fire (and climate change). Diorygopyx duplodentatus is a rarely collected species endemic to tall forests on high elevation ridges of the Great Dividing Range in northern NSW, with just four known localities. This species also should be regarded as Critically Endangered (IUCN, 2012).

\section{Spiny freshwater crayfishes}

All Australian freshwater crayfishes belong to the Southern Hemisphere family Parastacidae. Australia is the world centre of parastacid crayfish diversity, and includes the three largest and second smallest known species of freshwater crayfish (Ahyong, 2014). The modern distribution of Australian freshwater crayfishes, being in many respects relictual, reflects the increasing aridity of Australia since the mid-Miocene (Martin, 2006). The highest diversity is in the moist southeast of the continent, with comparatively few in the south-western corner and wet tropics of the northeast.

Euastacus, the largest parastacid genus, ranges from northern Queensland south to Victoria and eastern South Australia (McCormack, 2012; Ahyong, 2014). Most species of the genus favour cool, aerated, flowing water in lowland and high altitude habitats having forest cover or native riparian vegetation, usually with different species occupying different altitudinal ranges (Coughran, 2008). Consequently, the highest diversity is in the eastern drainages of southern NSW (38 species) (Ahyong, 2014; Crandall \& De Grave, 2017), substantially coinciding with the fire zone. Most species occupy narrow ranges, usually in the vegetated upper 
Table 4. The impact of the fire, measured using GEEBAM categories, on all spiny freshwater crayfish species that had $50 \%$ or more of their known occurrence burnt.

\begin{tabular}{|c|c|c|c|c|c|c|}
\hline \multirow[b]{2}{*}{ Crustaceans } & 2 & 3 & 4 & 5 & 6 & $4+5$ \\
\hline & low & medium & high & very high & $\begin{array}{l}\text { not native } \\
\text { vegetation }\end{array}$ & $\begin{array}{c}\text { total } \\
\text { high+very high }\end{array}$ \\
\hline Euastacus bidawalus & $0 \%$ & $0 \%$ & $100 \%$ & $0 \%$ & $0 \%$ & $100 \%$ \\
\hline Euastacus guwinus & $0 \%$ & $0 \%$ & $0 \%$ & $100 \%$ & $0 \%$ & $100 \%$ \\
\hline Euastacus vesper & $0 \%$ & $20 \%$ & $80 \%$ & $0 \%$ & $0 \%$ & $80 \%$ \\
\hline Euastacus "spinifex" & $7 \%$ & $0 \%$ & $36 \%$ & $43 \%$ & $0 \%$ & $79 \%$ \\
\hline Euastacus claytoni & $0 \%$ & $0 \%$ & $29 \%$ & $21 \%$ & $7 \%$ & $50 \%$ \\
\hline Euastacus yanga & $7 \%$ & $4 \%$ & $30 \%$ & $15 \%$ & $5 \%$ & $45 \%$ \\
\hline Euastacus clarkae & $45 \%$ & $9 \%$ & $27 \%$ & $0 \%$ & $0 \%$ & $27 \%$ \\
\hline Euastacus girurmulayn & $50 \%$ & $0 \%$ & $0 \%$ & $25 \%$ & $0 \%$ & $25 \%$ \\
\hline Euastacus pilosus & $38 \%$ & $8 \%$ & $15 \%$ & $0 \%$ & $8 \%$ & $15 \%$ \\
\hline $50-74 \%$ & & & & & & \\
\hline
\end{tabular}

reaches of single catchments, and as such the majority are Endangered or Critically Endangered under IUCN Red List criteria (Coughran \& Furse, 2010).

The ranges of 21 of 38 NSW species of Euastacus were impacted by the fires. Of these, the entire ranges of three species (E. "spinifer", E. guwinus and E. vesper) were burnt. Euastacus guwinus and E. vesper both have isolated distributions in the Shoalhaven and Cudgegong river catchments, respectively (Morgan, 1997; McCormack \& Ahyong, 2017). Euastacus "spinifer" has a wider range than the former two species, ranging from the Southern Highlands to the vicinity of Batemans Bay, Clyde River catchment. Although Euastacus spinifer is currently considered a wideranging species in NSW (McCormack, 2012), population analyses indicate that the southern population of E. spinifer, herein referred to as E. "spinifer", is a separate species, currently under detailed evaluation (Van De Wal, 2020). For these three highly impacted species, $79-100 \%$ of the burnt sites were also in the high to very high GEEBAM categories (Fig. 3B, Table 4), suggesting high fire intensities in these areas. The mosaic nature of burn impacts within the fire zone provides at least a degree of hope that not all species will have been equally affected. In this vein, the range of the Critically Endangered Fitzroy Falls spiny crayfish (Euastacus dharawhalus) (McCormack, 2013), which is endemic to a small area in the vicinity of Fitzroy Falls, Southern Highlands, was surprisingly but fortunately not affected by fire. For a fourth species, E. bidawalus, the entire NSW range was within the fire zone, but that species ranges into unburnt areas of Victoria as well.

Although the most direct impacts of fire are on terrestrial habitats, degradation of stream water quality within and downstream of burnt areas can be expected to have significant effects on the aquatic fauna, especially spiny crayfishes. These fire impacts are likely to have been accentuated by the effects of the preceding years of extended drought on the small streams and creeks occupied by Euastacus. Even if temporary elevation of water temperatures can be avoided by retreat into deep burrows, subsequent exposure to toxins released by burning, eutrophication and anoxia caused by excessive organic deposition and runoff can nevertheless be detrimental (New, 2014; Emelko et al., 2016; Harper et al., 2019). Although some aquatic crustaceans have demonstrated resilience to habitat burning (Driessen, 2019), little is known about fire resilience of crayfishes, such as Euastacus, which typically favour cool, well-oxygenated, oligotrophic waters. In addition, species of Euastacus regularly leave the stream to forage. Therefore, for spiny crayfishes, fire has probably not only affected the immediate aquatic environment, but also important terrestrial food sources. Going forward, finely granular ground-truthing of the extent of fire in the catchments of spiny crayfishes, together with population assessments, are required to evaluate the fire impacts on NSW species of Euastacus.

\section{Drosophilid flies}

Australian drosophilid flies are largely restricted to a narrow band of wet or humid forest habitats along the eastern side of the continent from northern Queensland to Victoria and Tasmania. Species diversity attenuates southwards (McEvey, 2020b). New Guinea has an estimated 1000 species and the Australian drosophilid fauna (281 species) can best be understood as a subset of that, with limited secondary radiations in the subtropical rainforests of southern Queensland and north-eastern NSW (McEvey, 2020a). New South Wales has 130 species, 123 of which have been filtered out for study using the criteria given in Methods. Low humidity and desiccation stress are significant in defining the limits of species distribution (Kellermann et al., 2020). In montane forests, flies descend (compelled by positive hydrotropism, positive geotaxis, and negative phototaxis) to damp gullies during periods of high wind and low humidity, conditions which precede bushfire events. Indeed, many species are never found away from damp gullies. Mycophagous species, for example, which comprise about $40 \%$ of the fauna, occur only in close association with fleshy, soft fungal growths - such growths are also dependent on high humidity and low solar radiation levels. Consequently, many drosophilid species in the AM collection have been collected in autumn, in gullies on fungi. Many species are absent in fly collections at other times of the year, or in collections from sclerophyll or xeric habitats. Vagility is very low, so active movement over distances exceeding several hundred metres is very unlikely (Coyne et al., 1982). When adult flies are present at any one locality during warm humid conditions, the questions arise: $(a)$ were they present throughout the year in arrested diapause? (b) have they arrived by active migration? or (c) have they arrived by passive and random dispersal, for example, by wind? Most evidence (Dobzhansky, 1973) suggests that they are locally 
Table 5. The impact of the fire, measured using GEEBAM categories, on all drosophilid fly species that had $50 \%$ or more of their known occurrence burnt.

\begin{tabular}{|c|c|c|c|c|c|c|}
\hline & 2 & 3 & 4 & 5 & 6 & $4+5$ \\
\hline Flies & low & medium & high & very high & $\begin{array}{l}\text { not native } \\
\text { vegetation }\end{array}$ & $\begin{array}{c}\text { total } \\
\text { high+very high }\end{array}$ \\
\hline Acletoxenus formosus & $0 \%$ & $0 \%$ & $0 \%$ & $100 \%$ & $0 \%$ & $100 \%$ \\
\hline Leucophenga subpollinosa & $0 \%$ & $0 \%$ & $100 \%$ & $0 \%$ & $0 \%$ & $100 \%$ \\
\hline Scaptodrosophila eluta & $0 \%$ & $0 \%$ & $100 \%$ & $0 \%$ & $0 \%$ & $100 \%$ \\
\hline Scaptodrosophila ehrmanae & $0 \%$ & $20 \%$ & $40 \%$ & $20 \%$ & $0 \%$ & $60 \%$ \\
\hline Scaptodrosophila anthemon & $0 \%$ & $0 \%$ & $0 \%$ & $50 \%$ & $0 \%$ & $50 \%$ \\
\hline Scaptodrosophila insolita & $25 \%$ & $25 \%$ & $0 \%$ & $25 \%$ & $0 \%$ & $25 \%$ \\
\hline Leucophenga domanda & $50 \%$ & $0 \%$ & $0 \%$ & $0 \%$ & $0 \%$ & $0 \%$ \\
\hline Scaptodrosophila jackeyi & $100 \%$ & $0 \%$ & $0 \%$ & $0 \%$ & $0 \%$ & $0 \%$ \\
\hline
\end{tabular}

$50-74 \% \square 75-99 \% \square 100 \%$ burnt

permanent (or sedentary) and that their abundance fluctuates from undetectable lows (almost absent) to high frequency abundance (frequently encountered by collectors).

During the recent fires, NSW humid forest habitats have been unusually impacted because of coincident drought conditions. At many localities, habitats normally offering suitable protection from desiccation stress were burnt, opening the forest canopy to unusually high levels of sunlight, heat and air flow. Among the drosophilid flies in this study, 75 species have distributions in areas impacted by the bushfires. Figure $2 \mathrm{C}$ and Tables 1 and 2 show that four species had their known ranges in NSW completely burnt. However, all four are widespread species common in Queensland and elsewhere, but rare in NSW. These species will perhaps be absent in NSW collections for some decades, or perhaps be discovered in adjacent suitable localities. Of the remaining 71 species, 66 are known to occur in localities that were burnt to varying extent in NSW. These 66 species also have distributions extending outside NSW into Queensland or Victoria or elsewhere and are therefore not facing the threat of extinction. Five remaining species are noteworthy because they have small ranges, not extending outside NSW, and large parts of those ranges have been damaged by fire.

Scaptodrosophila ehrmanae is a cool-adapted species of ferny gullies of Victoria and NSW, 80\% of the known localities in NSW have been burnt. Scaptodrosophila insolita, on the other hand, is rare in collections; only five specimens are known, all are from NSW (McEvey, 2020a), and $50 \%$ of its known range has been burnt. Scaptodrosophila minnamurrae is not uncommon, it is apparently found only in NSW at numerous localities, $30 \%$ of which have been fire-affected. Scaptodrosophila vindicta is a species of the rainforests of Barrington Tops and nearby lowland rainforests (McEvey, 2020a), 25\% of those localities have been burnt. Leucophenga cyanorosa is a very striking species with patterned wings (McEvey, 2018), restricted to NSW montane wet temperate forests of the Blue Mountains, Barrington Top and further north (McEvey, 2020a); fire has affected 38\% of the localities where it is known.

\section{Land snails}

Australia harbours approximately 1600 currently accepted species of terrestrial snails, many of them poorly known. In addition, there are claims of several hundred undescribed species (Stanisic et al., 2010). The need to conserve water is a major driving factor in land snail behaviour and distribution (Solem, 1978), and in eastern Australia, the largest diversity of land snails is found in rainforests where there is high rainfall and humidity (Smith \& Stanisic, 1998). Only a relatively small proportion of the fauna has made the transition to dry eucalypt forests. Dry rainforest (including auricarian vine forest, semi-evergreen vine thicket and coastal thickets) and limestone outcrops also form an important habitat type for many land snails, acting as moisture-retaining refugia often surrounded by less hospitable dry sclerophyll forest (Smith \& Stanisic, 1998; Stanisic et al., 2010). The snail fauna found in these isolated areas tends to show high levels of endemicity (Stanisic, 2005; Stanisic et al., 2010).

There are 856 land snails recorded from NSW in the AM collections, including presumably undescribed candidate species referred to by code-names. These were cleaned and filtered to 341 species for the purposes of this analysis (as described in Methods; specifically undescribed candidate taxa have been removed from the dataset). Over $60 \%$ of these species were affected by the recent bushfires. The 11 species that had their known ranges completely contained in the fire zone are all restricted species with narrow ranges, each with fewer than 10 records in the AM collections (and in most cases, with only one or two records). The majority (nine species) are rainforest or limestone-associated species belonging to the family Charopidae. Charopids are a very diverse group of small to minute snails, with most Australian species fewer than $5 \mathrm{~mm}$ in shell diameter (Stanisic et al., 2010). They number over 200 species in Australia, with an estimated 300+ undescribed species (Stanisic, 1998; Shea et al., 2012). Most charopids have narrow distributions, but are often under-represented in collections due to their small size. An additional six charopid species had up to $50 \%$ of their known ranges burnt.

Another group of snails heavily affected by the fires is the genus Austrochloritis (family Camaenidae), one of the most speciose genera in eastern Australia, currently numbering 34 accepted species (Shea \& Köhler, 2019). One Austrochloritis species has had all of its known range burnt, while another six Austrochloritis species and two other closely related camaenids have had up to $50 \%$ of their known ranges burnt. There are also likely to be additional, undescribed species of Austrochloritis within the burnt regions (Shea \& Köhler, 2019). Camaenids are Australia's largest group of land snails, with an estimated 700-800 species (Solem, 1998). Camaenid species have narrow ranges and many have adapted to drier environments, with a great diversity of species known from 
Table 6. The impact of the fire, measured using GEEBAM categories, on all land snail species that had $50 \%$ or more of their known occurrence burnt.

\begin{tabular}{|c|c|c|c|c|c|c|}
\hline & 2 & 3 & 4 & 5 & 6 & $4+5$ \\
\hline Snails & low & medium & high & very high & $\begin{array}{l}\text { not native } \\
\text { vegetation }\end{array}$ & $\begin{array}{c}\text { total } \\
\text { high+very high }\end{array}$ \\
\hline Egilodonta bendethera & $0 \%$ & $0 \%$ & $0 \%$ & $100 \%$ & $0 \%$ & $100 \%$ \\
\hline Meredithena marysvillensis & $33 \%$ & $0 \%$ & $67 \%$ & $0 \%$ & $0 \%$ & $67 \%$ \\
\hline Hedleyropa yarrangobillyensis & $25 \%$ & $0 \%$ & $0 \%$ & $50 \%$ & $25 \%$ & $50 \%$ \\
\hline Macleayropa boonanghi & $0 \%$ & $0 \%$ & $50 \%$ & $0 \%$ & $0 \%$ & $50 \%$ \\
\hline Oreomava cannfluviatilus & $6 \%$ & $6 \%$ & $13 \%$ & $38 \%$ & $0 \%$ & $50 \%$ \\
\hline Planorbacochlea dandahra & $50 \%$ & $0 \%$ & $50 \%$ & $0 \%$ & $0 \%$ & $50 \%$ \\
\hline Vitellidelos kaputarensis & $0 \%$ & $11 \%$ & $47 \%$ & $0 \%$ & $5 \%$ & $47 \%$ \\
\hline Gyrocochlea janetwaterhouseae & $43 \%$ & $14 \%$ & $29 \%$ & $14 \%$ & $0 \%$ & $43 \%$ \\
\hline Austrochloritis abrotonus & $8 \%$ & $4 \%$ & $20 \%$ & $22 \%$ & $5 \%$ & $42 \%$ \\
\hline Gyrocochlea gibraltar & $33 \%$ & $0 \%$ & $33 \%$ & $0 \%$ & $0 \%$ & $33 \%$ \\
\hline Macrophallikoropa stenoumbilicata & $0 \%$ & $67 \%$ & $0 \%$ & $33 \%$ & $0 \%$ & $33 \%$ \\
\hline Protorugosa alpica & $44 \%$ & $0 \%$ & $33 \%$ & $0 \%$ & $0 \%$ & $33 \%$ \\
\hline Austrochloritis kaputarensis & $6 \%$ & $24 \%$ & $12 \%$ & $18 \%$ & $0 \%$ & $29 \%$ \\
\hline Austrochloritis seaviewensis & $0 \%$ & $44 \%$ & $25 \%$ & $0 \%$ & $6 \%$ & $25 \%$ \\
\hline Pommerhelix monacha & $2 \%$ & $8 \%$ & $14 \%$ & $9 \%$ & $19 \%$ & $23 \%$ \\
\hline Austrochloritis marksandersi & $46 \%$ & $0 \%$ & $0 \%$ & $15 \%$ & $8 \%$ & $15 \%$ \\
\hline Austrochloritis wollemiensis & $8 \%$ & $6 \%$ & $8 \%$ & $4 \%$ & $50 \%$ & $13 \%$ \\
\hline Planorbacochlea manningensis & $0 \%$ & $60 \%$ & $0 \%$ & $10 \%$ & $0 \%$ & $10 \%$ \\
\hline Rhophodon kempseyensis & $10 \%$ & $30 \%$ & $0 \%$ & $10 \%$ & $0 \%$ & $10 \%$ \\
\hline Kandoschloritis pustulosus & $36 \%$ & $9 \%$ & $9 \%$ & $0 \%$ & $9 \%$ & $9 \%$ \\
\hline Austrochloritis kippara & $0 \%$ & $50 \%$ & $0 \%$ & $0 \%$ & $50 \%$ & $0 \%$ \\
\hline Austrochloritis paucisetosa & $57 \%$ & $0 \%$ & $0 \%$ & $0 \%$ & $0 \%$ & $0 \%$ \\
\hline Coricudgia wollemiana & $0 \%$ & $100 \%$ & $0 \%$ & $0 \%$ & $0 \%$ & $0 \%$ \\
\hline Egilomen sebastopol & $0 \%$ & $100 \%$ & $0 \%$ & $0 \%$ & $0 \%$ & $0 \%$ \\
\hline Letomola lanalittleae & $0 \%$ & $0 \%$ & $0 \%$ & $0 \%$ & $100 \%$ & $0 \%$ \\
\hline Prolesophanta occlusa & $29 \%$ & $0 \%$ & $0 \%$ & $0 \%$ & $29 \%$ & $0 \%$ \\
\hline Rhophodon palethorpei & $0 \%$ & $0 \%$ & $0 \%$ & $0 \%$ & $100 \%$ & $0 \%$ \\
\hline Sigaloeista gracilis & $100 \%$ & $0 \%$ & $0 \%$ & $0 \%$ & $0 \%$ & $0 \%$ \\
\hline
\end{tabular}

semi-arid habitats in central and Western Australia (Solem, 1998). Many species of Austrochloritis inhabit dry woodland and heath as well as rainforest (Stanisic et al., 2010), thus increasing their susceptibility to bushfires.

Two other groups affected by the bushfires are the families Helicarionidae and Rhytididae. Helicarionid species Sigaloeista gracilis is only represented in our analysis by a single site in Gibraltar Range National Park, which was burnt in the 2019-2020 fires. However, the species is also recorded from Richmond Range National Park (Köhler, 2019), an area that was not burnt. Helicarionids are primarily rainforest-dwelling species, with most of their diversity in southeastern Queensland. Many of the species present in the burnt areas of NSW have relatively broad ranges as currently defined (Hyman et al., 2017; Köhler, 2018a,b). However, the widespread helicarionid semislug Helicarion cuvieri has numerous genetically distinct clades that may prove to be recently diverged, geographically restricted species (Köhler, 2018a), several of which are likely to have been negatively impacted by the bushfires.

There were no rhytidid species that suffered $100 \%$ habitat destruction as a result of the bushfires, but three species had $57-71 \%$ of their known distribution burnt. Rhytidids are carnivorous snails found primarily in wet forest areas (Smith, 1998). The majority of species prey upon other native snails.
Among the most heavily affected species, a high proportion live exclusively in rainforest or in limestoneassociated woodland, regions that will recover slowly from the bushfires. This category also contains a disproportionate number of minute species with a shell diameter of less than $5 \mathrm{~mm}$. These species are difficult to find and are often under-represented in surveys, giving hope that they may be present in other unburnt areas. Follow-up surveys will require specialists and special techniques for targeting minute snails.

\section{Spiders}

Mygalomorph spiders are long-lived, reside in burrows and are highly sedentary (Raven \& Wishart, 2006). Owing to their subterranean lifestyle, it might be assumed that they are relatively immune to the effects of bushfires. However, a recent study of high-intensity and low-intensity fires in urban areas in Western Australia found high mortality of burrowing mygalomorph spiders after high-intensity fires (100\% mortality after a year) (Mason et al., 2019). Mortality was much lower for low-intensity fires. Many mygalomorph spiders have narrow ranges and thus may be vulnerable to extinction from high-intensity fires.

Three of the five mygalomorph species with $100 \%$ of their known ranges burnt belong to the genus Arbanitis 
Table 7. The impact of the fire, measured using GEEBAM categories, on all mygalomorph and archaeid spider species that had $50 \%$ or more of their known occurrence burnt.

\begin{tabular}{|c|c|c|c|c|c|c|}
\hline \multirow[b]{2}{*}{ Spiders } & 2 & 3 & 4 & 5 & 6 & $4+5$ \\
\hline & low & medium & high & very high & $\begin{array}{l}\text { not native } \\
\text { vegetation }\end{array}$ & $\begin{array}{c}\text { total } \\
\text { high+very high }\end{array}$ \\
\hline Aname caeruleomontana & $0 \%$ & $0 \%$ & $100 \%$ & $0 \%$ & $0 \%$ & $100 \%$ \\
\hline Arbanitis macei & $0 \%$ & $0 \%$ & $100 \%$ & $0 \%$ & $0 \%$ & $100 \%$ \\
\hline Ixamatus fischeri & $0 \%$ & $0 \%$ & $0 \%$ & $86 \%$ & $0 \%$ & $86 \%$ \\
\hline Cethegus barraba & $0 \%$ & $0 \%$ & $50 \%$ & $0 \%$ & $0 \%$ & $50 \%$ \\
\hline Paraembolides boydi & $4 \%$ & $0 \%$ & $39 \%$ & $9 \%$ & $4 \%$ & $48 \%$ \\
\hline Carrai afoveolata & $36 \%$ & $18 \%$ & $0 \%$ & $45 \%$ & $0 \%$ & $45 \%$ \\
\hline Arbanitis mascordi & $14 \%$ & $0 \%$ & $14 \%$ & $0 \%$ & $0 \%$ & $14 \%$ \\
\hline Atrax yorkmainorum & $2 \%$ & $2 \%$ & $5 \%$ & $0 \%$ & $58 \%$ & $5 \%$ \\
\hline Arbanitis helensmithae & $100 \%$ & $0 \%$ & $0 \%$ & $0 \%$ & $0 \%$ & $0 \%$ \\
\hline Arbanitis horsemanae & $100 \%$ & $0 \%$ & $0 \%$ & $0 \%$ & $0 \%$ & $0 \%$ \\
\hline Hadronyche emmalizae & $0 \%$ & $14 \%$ & $0 \%$ & $0 \%$ & $57 \%$ & $0 \%$ \\
\hline Ixamatus musgravei & $0 \%$ & $50 \%$ & $0 \%$ & $0 \%$ & $0 \%$ & $0 \%$ \\
\hline $50-74 \%$ & & & & & & \\
\hline
\end{tabular}

(Idiopidae). Arbanitis is widely distributed in eastern and southeastern Australia (Rix et al., 2017) and most species appear to have limited ranges (Wishart \& Rowell, 2008). Similarly, the other two species concerned, Carrai afoveolata (Euagridae) and Chenistonia caeruleomontana (Anamidae) are only known from their type localities and must be assumed to be vulnerable to extinction. Follow-up surveys would need to include pitfall trapping as adult males are usually needed for species identification of mygalomorph spiders.

Archaeid spiders are litter dwellers with narrow species distributions and could be expected to be severely impacted by high-intensity fires. The Australian endemic genus Austrarchaea includes a number of relictual, largely shortrange endemic species (Rix \& Harvey, 2011).

The three species with $100 \%$ of their known ranges burnt are $A$. monteithi, known only from the type locality; $A$. smithae, known with certainty only from Mount Wilson in the Blue Mountains; and A. mcguiganae, known only from Monga National Park. All of the specimens of these species that were directly collected came from sifting elevated leaf litter, suggesting they would be particularly susceptible to intense fires.

\section{Comparisons and limitations}

A list of priority invertebrate species for urgent management intervention has been released by the Australian Government, using similar techniques to the current study but sourcing species distribution data from the Atlas of Living Australia (ALA) (DAWE, 2020a). Species were included on the list if more than $30 \%$ of their known range was burnt, with the exception of the land snails, where only those species with more than $50 \%$ of their known habitat burnt were listed. The compilation of such a list is always hampered by the lack of information available on many poorly known taxonomic groups. Consequently, our study has revealed some additional species that should be considered a priority for management intervention.
We identified an additional seven species of land snails with more than $50 \%$ of their known NSW range burnt, as well as an extra 27 species of dung beetles, three freshwater crayfishes, 17 drosophilid flies, 27 land snails and 19 spiders with more than $30 \%$ of their known range in NSW burnt (see Table 2). These species included two beetles, two freshwater crayfishes, four flies, two land snails and eight spiders falling in the $100 \%$ burnt category that had not previously been identified as high priority.

Directly comparing the results of our study with the existing priority list revealed some of the limitations of the study method. It was apparent that the use of differing methods and datasets affected results. For example, comparing the land snails listed as priority based on ALA records (DAWE, 2020a) to the current study based on AM collection data shows that while the majority of species were found in both studies, each study identified some species that the other did not. Our study failed to identify species that are not present in the AM collections but are held in other Australian museums, while the Australian Government's priority list did not identify a number of species described in the last 10 years that are not listed on the Atlas of Living Australia.

There were also considerable differences in the estimation of the percentage of habitat burnt for some species. For species where records are very scant, the addition or removal of a single extra site can change the categorization substantially. The data were also sensitive to the removal of older records and the removal of duplicate sites, all of which may have contributed to discrepancies between the two studies.

Finally, a limitation of both studies lies in the assumption that collection records reflect the current distribution. In the majority of cases collections records probably underrepresent the actual range (especially for small or very cryptic species), but in the case of declining populations it may also be an over-estimation. It is now vital that distributions are confirmed with on-ground surveys in order to assess the current status of species identified as highest risk. 


\section{Outcomes and consequences}

The bushfires that raged through eastern Australia in 2019-2020 are part of a growing number of large-scale fires seen around the world in recent years, linked to humaninduced climate change (Mantgem et al., 2014; Jolly et al., 2015; Fonesca et al., 2017) as well as other factors, such as land use and logging (Lindenmayer et al., 2020). Changes to land management and action on climate change are being called for (Lindenmayer et al., 2020; Nature Climate Change editorial-Anonymous, 2020b), but it is likely that the risk of extensive fires will remain high.

There is now an urgent need for field studies assessing the impact of these bushfires, both in the short- and longterm. The Australian Government has released reports listing priority species of vertebrates, invertebrates and plants that require management intervention (Legge et al., 2020; DAWE, 2020a,b). Recommendations include immediate on-ground assessment and protection of adjacent unburnt areas. The current study has confirmed the placement of 41 species on this list and added an additional 103 species that are recorded as having $30 \%$ or more of their habitat burnt.

The impacts of the bushfires are likely to have been more severe on species that inhabit forest types that are normally not prone to fires (e.g., rainforests) than those inhabiting forest types which experience fires more regularly (e.g., dry sclerophyll forests). Furthermore, the consequences of local extinctions and declines are more critical for the survival of species with comparatively low fecundity, low dispersal ability and/or narrow distributional ranges. Thousands of species of invertebrates meet these criteria, many of them likely to be undescribed, and the risk of a wave of extinctions is very real. Prioritizing assessment of the species that data suggests are the most vulnerable, and monitoring the response and recovery of our native fauna, will be critical in understanding and mitigating the short-term and long-term impact of mega-bushfires.

\section{References}

ABARES, 2019. Australian forest profiles: Australia's forests. Canberrra: Australian Bureau of Agricultural and Resource Economics and Sciences. https://doi.org/10.25814/5d915bf94241b

Ahyong, S. T. 2014. Diversity and distribution of Australian freshwater crayfish with a check-list of the world Parastacidae and key to the genera (Decapoda: Astacidea: Parastacoidea), ed. D.C.J. Yeo, N. Cumberlidge, and S. Klaus. Advances in Freshwater Decapod Crustacean Systematics and Biology. Crustaceana Monographs 19: 245-271.

https://doi.org/10.1163/9789004207615_015

Ahyong, S. T. 2020. Geospatial coordinate data for 38 species of Spiny Freshwater Crayfishes (Parastacidae) from New South Wales. figshare. Dataset

https://doi.org/10.6084/m9.figshare. 12806747

Anonymous, 2020a. Atlas of Living Australia. Scarabaeinae. [Accessed 31 July 2020]

https://bie.ala.org.au/species/urn:Isid:biodiversity.org.au:afd.

taxon:774c12ac-6525-4bb6-be3b-ab1df675d906\#classification

Anonymous. 2020b. In the line of fire. Nature Climate Change 10(3): 169.

https://doi.org/10.1038/s41558-020-0720-5
Buckingham, S., N. Murphy, and H. Gibb. 2019. Effects of fire severity on the composition and functional traits of litterdwelling macroinvertebrates in a temperate forest. Forest Ecology and Management 434: 279-288. https://doi.org/10.1016/j.foreco.2018.12.030

Chapman, A. D. 2009. Numbers of Living Species in Australia and the World. 2nd Edition. Canberra: Australian Biological Resources Study.

http://www.environment.gov.au/science/abrs/publications/other/

numbers-living-species/contents/

Coughran, J. 2008. Distinct groups in the genus Euastacus? Freshwater Crayfish 16: 123-130.

Coughran, J., and J. M. Furse. 2010. An assessment of genus Euastacus (49 species) Versus IUCN Red List Criteria. Report prepared for the global species conservation assessment of crayfishes for the IUCN Red List of Threatened Species. Alabama, USA: International Association of Astacology, pp. vi+170.

Coyne, J. A., I. A. Boussy, T. Prout, S. H. Bryant, J. S. Jones, and J. A. Moore. 1982. Long-distance migration of Drosophila. The American Naturalist 119(4): 589-595.

https://doi.org/10.1086/283936

Crandall, K. A., and S. De Grave. 2017. An updated classification of the freshwater crayfishes (Decapoda: Astacidea) of the world, with a complete species list. Journal of Crustacean Biology 37: 615-653. https://doi.org/10.1093/jcbiol/rux070

DAWE, see under Department of Agriculture, Water and the Environment, Australian Government.

Department of Agriculture, Water and the Environment. 2020a. Provisional list of priority invertebrate species requiring urgent management intervention or on-ground assessment. Canberra: Department of Agriculture, Water and the Environment, Australian Government.

https://www.environment.gov.au/biodiversity/bushfire-recovery/

priority-invertebrates

Department of Agriculture, Water and the Environment. 2020b. Provisional list of plants requiring urgent management intervention. 23 April, 2020. Canberra: Department of Agriculture, Water and the Environment, Australian Government https://www.environment.gov.au/biodiversity/bushfire-recovery/priority-plants/

Department of Planning, Industry and Environment. 2020. Wildlife and Conservation Bushfire Recovery: Immediate Response January 2020. Sydney: Environment, Energy and Science: Department of Planning, Industry and Environment, NSW State Government.

https://www.environment.nsw.gov.au/research-and-publications/

publications-search/wildlife-and-conservation-bushfire-recovery-immediate-response/

DPIE, see under Department of Planning, Industry and Environment, New South Wales State Government.

Dobzhansky, T. 1973. Active dispersal and passive transport in Drosophila. Evolution 27: 565-575. https://doi.org/10.1111/j.1558-5646.1973.tb00706.x

Driessen, M. M. 2019. Fire resilience of a rare, freshwater crustacean in a fire-prone ecosystem and the implications for fire management. Austral Ecology 44(6): 1030-1039. https://doi.org/10.1111/aec.12770

Ebert, K. M., G. B. Monteith, R. Menendez, and D. J. Merritt. 2019. Bait preferences of Australian dung beetles (Coleoptera: Scarabaeidae) in tropical and subtropical Queensland forests. Austral Entomology 58(4): 772-782.

https://doi.org/10.1111/aen.12396

Edwards, P., P. Wilson, and J. Wright. 2015. Introduced Dung Beetles in Australia. A Pocket Field Guide, 3rd edition. Clayton, Victoria: CSIRO Publishing, 69pp. https://doi.org/10.1071/9781486300709

Emelko, M. B., M. Stone, U. Silins, D. Allin, A. L. Collins, C. H. Williams, A. M. Martens, and K. D. Bladon. 2016. Sedimentphosphorus dynamics can shift aquatic ecology and cause downstream legacy. Global Change Biology 22(3): 1168-1184. https://doi.org/10.1111/gcb.13073 
Fahrig, L. 2003. Effects of habitat fragmentation on biodiversity. Annual Review of Ecology, Evolution, and Systematics 34: 487-515.

https://doi.org/10.1146/annurev.ecolsys.34.011802.132419

Fonseca, M. G., L. O. Anderson, E. Arai, Y. E. Shimabukuro, H. A. M. Xaud, M. R. Xaud, N. Madani, F. H. Wagner, and L. E. O. C. Aragão. 2017. Climatic and anthropogenic drivers of northern Amazon fires during the 2015-2016 El Niño event. Ecological Applications 27: 2514-2527.

https://doi.org/10.1002/eap.1628

GEEBAM, 2020. Google Earth Engine Burnt Area Map GEEBAM. https://datasets.seed.nsw.gov.au/dataset/

google-earth-engine-burnt-area-map-geebam

Gollan, J. R., C. A. M. Reid, P. Barnes, and L. Wilkie. 2011. The ratio of exotic-to-native dung beetles can indicate habitat quality in riparian restoration. Insect Conservation and Diversity 4: 123-131.

https://doi.org/10.1111/j.1752-4598.2010.00115.x

Gunter, N., C. Lemann, and T. A. Weir. 2019. 30. Scarabaeidae: Scarabaeinae Latreille, 1802. In Australian beetles Volume 2. Archostemata, Myxophaga, Adephaga, Polyphaga (part), ed. A. Ślipiński and J. F. Lawrence, pp. 443-466. Clayton, Victoria: CSIRO Publishing.

Gunter, N., and T. Weir. 2017. Two new genera of Australian dung beetles (Coleoptera: Scarabaeidae: Scarabaeinae) with the description of six new species and transfer of six described species. Zootaxa 4290(2): 201-243. https://doi.org/10.11646/zootaxa.4290.2.1

Gunter, N., and T. Weir. 2019. Revision of Australian species of the dung beetle genus Lepanus (Coleoptera: Scarabaeidae: Scarabaeinae): description of 10 new species from the $L$. australis, L. monteithi and $L$. villosus species groups. Zootaxa 4695(3): 201-252. https://doi.org/10.11646/zootaxa.4695.3.1

Harper, A. R., C. Santin, S. H. Doerr, C. A. Froyd, D. Albini, X. L. Otero, L. Viñas, and B. Pérez-Fernández. 2019. Chemical composition of wildfire ash produced in contrasting ecosystems and its toxicity to Daphnia magna. International Journal of Wildland Fire 28: 726-737.

https://doi.org/10.1071/WF18200

Harris, R., and C. Reid. 2016. Dung Beetles of Eastern New South Wales. [Accessed September 2020]

https://keys.lucidcentral.org/keys/v3/aus_museum/dung_beetles/

Hewitt, J. E., S. F. Thrush, J. Halliday, and C. Duffy. 2005. The importance of small-scale habitat structure for maintaining beta diversity. Ecology 86: 1619-1626. https://doi.org/10.1890/04-1099

Hyman, I. T., and F. Köhler. 2018a. Reconciling comparative anatomy and mitochondrial phylogenetics in revising species limits in the Australian semislug Helicarion Férussac, 1821 (Gastropoda: Stylommatophora). Zoological Journal of the Linnean Society 184: 933-968. https://doi.org/10.1093/zoolinnean/zly017

Hyman, I. T., and F. Köhler. 2018b. A revision of eastern Australian land snails placed in Nitor Gude (Helicarionidae, Stylommatophora). Invertebrate Systematics 32: 1171-1205. https://doi.org/10.1071//S18015

Hyman, I. T., and F. Köhler. 2019. Revision of Sigaloeista Shea \& Griffiths, 2010 (Helicarionidae, Gastropoda, Stylommatophora) from eastern Australia. Molluscan Research 39(2): 171-189. https://doi.org/10.1080/13235818.2018.1471973

Hyman, I. T., and J. Stanisic. 2005. New charopid land snails chiefly from limestone outcrops in NSW (Eupulmonata: Charopidae). Memoirs of the Queensland Museum 50(2): 219-302.

Hyman, I. T., I. de la Iglesia Lamborena, and F. Köhler. 2017. Molecular phylogenetics and systematic revision of the south-eastern Australian Helicarionidae (Gastropoda, Stylommatophora). Contributions to Zoology 86(1): 51-95. https://doi.org/10.1163/18759866-08601004

IUCN. 2012. IUCN Red List Categories and Criteria: Version 3.1, 2nd edition. Gland, Switzerland and Cambridge, UK: IUCN (International Union for Conservation of Nature), iv $+32 \mathrm{pp}$. https://portals.iucn.org/library/sites/library/files/documents/RL-2001-001-2nd.pdf
Jolly, W. M., M. A. Cochrane, P. H. Freeborn, Z. A. Holden, T. J. Brown, G. J. Williamson, and D. M. J. S. Bowman. 2015. Climate-induced variations in global wildfire danger from 1979 to 2013. Nature Communications 6: 7537. https://doi.org/10.1038/ncomms8537

Kellermann, V., S. F. McEvey, C. M. Sgrò, and A. A. Hoffmann. 2020. Phenotypic plasticity for desiccation resistance, climate change and future species distributions: will plasticity have much impact? The American Naturalist 196(3): 306-315. https://doi.org/10.1086/710006

Köhler, F., and I. T. Hyman. 2020. Geospatial co-ordinate data for 345 land snail species from New South Wales. figshare. Dataset. https://doi.org/10.6084/m9.figshare. 13012649

Lane, A., K. Wallis, and S. Phillips. 2020. A review of the conservation status of New South Wales populations of the Koala (Phascolarctos cinereus) leading up to and including part of the 2019/20 fire event. Report to International Fund for Animal Welfare (IFAW). Uki, NSW: Biolink Ecological Consultants.

Lawton, J., D. Bignell, B. Bolton, G. F. Bloemers, P. Eggleton, P. M. Hammond, M. Hodda, R. D. Holt, T. B. Larsen, N. A. Mawsdley, N. E. Stork, D. S. Srivastava, and A. D. Watt. 1998. Biodiversity inventories, indicator taxa and effects of habitat modification in tropical forest. Nature 391: 72-76. https://doi.org/10.1038/34166

Legge, S., J. Woinarski, S. Garnett, D. Nimmo, B. Scheele, M. Lintermans, N. Mitchell, N. Whiterod, and J. Ferris. 2020. Rapid analysis of impacts of the 2019-20 fires on animal species, and prioritisation of species for management response. Report prepared for the Wildlife and Threatened Species Bushfire Recovery Expert Panel, 14 March 2020. Technical Report, published by the Department of Agriculture, Water and the Environment, Canberra.

https://www.environment.gov.au/biodiversity/bushfire-recovery/

research-and-resources/

Lindenmayer, D. B., R. M. Kooyman, C. Taylor, M. Ward, and J. E. M. Watson. 2020. Recent Australian wildfires made worse by logging and associated forest management. Nature Ecology and Evolution 4: 898-900.

https://doi.org/10.1038/s41559-020-1195-5

Mantgem, P. J., J. C. B. Nesmith, M. Keifer, E. E. Knapp, A. Flint, and L. Flint. 2013. Climatic stress increases forest fire severity across the western United States. Ecology Letters 16: $1151-1156$. https://doi.org/10.1111/ele.12151

Martin, H. 2006. Cenozoic climatic change and the development of the arid vegetation in Australia. Journal of Arid Environments 66(3): 533-563. https://doi.org/10.1016/j.jaridenv.2006.01.009

Mason, L., P. W. Bateman, B. P. Mill, and G. W. Wardell-Johnson. 2019. Ashes to ashes: intense fires extinguish populations of urban short-range endemics. Austral Ecology 44(3): 514-522. https://doi.org/10.1111/aec.12685

Matthews, E. G. 1972. A revision of the scarabaeine dung beetles of Australia. I. Tribe Onthophagini. Australian Journal of Zoology, Supplementary Series 9: 1-330. https://doi.org/10.1071/AJZS009

Matthews, E. G. 1974. A revision of the scarabaeine dung beetles of Australia. 2. Tribe Scarabaeini. Australian Journal of Zoology, Supplementary Series 24: 1-211.

https://doi.org/10.1071/AJZS024

Matthews, E. G. 1976. A revision of the scarabaeine dung beetles of Australia. III. Tribe Coprini. Australian Journal of Zoology, Supplementary Series 38: 1-52.

https://doi.org/10.1071/AJZS038

McCormack, R. B. 2012. A Guide to Australia's Spiny Freshwater Crayfish. Melbourne: CSIRO Publishing, 235 pp. https://doi.org/10.1071/9780643103870

McCormack, R. B. 2013. Conservation status of imperiled freshwater crayfish Euastacus dharawalus (Decapoda: Astacidea: Parastacidae), from the Southern Highlands of New South Wales, Australia. Journal of Crustacean Biology 33(2): 432-439.

https://doi.org/10.1163/1937240X-00002138 
McCormack, R. B., and S. T. Ahyong. 2017. Euastacus vesper sp. nov., a new giant spiny crayfish (Crustacea, Decapoda, Parastacidae) from the Great Dividing Range, New South Wales, Australia. Zootaxa 4244: 556-567. https://doi.org/10.11646/zootaxa.4244.4.6

McEvey, S. F. 2018. High resolution diagnostic images of Leucophenga cyanorosa Bock, 1979 (Diptera: Drosophilidae). figshare. Figure.

https://doi.org/10.6084/m9.figshare.5866998

McEvey, S. F. 2020a. Geospatial coordinate data for 125 species of New South Wales Drosophilidae (Diptera). figshare. Dataset. https://doi.org/10.6084/m9.figshare.11987538

McEvey, S. F. 2020b. Results of Drosophilidae (Diptera) invertebrate fauna surveys of north-east NSW forests. North East Forests Biodiversity Study Report No. 3d. figshare. Online resource, first published in print by NSW NPWS 1994. https://doi.org/10.6084/m9.figshare.11691777

Milledge, G. 2020. Dataset of Mygalomorph and Archaeid spiders from NSW, Australia. figshare. Dataset. https://doi.org/10.6084/m9.figshare.13023032

Morgan, G. J. 1997. Freshwater crayfish of the genus Euastacus Clark (Decapoda: Parastacidae) from New South Wales, with a key to all species of the genus. Records of the Australian Museum, Supplement 23: 1-110. https://doi.org/10.3853/j.0812-7387.23.1997.429

New, T. R. 2014. Insects, Fire and Conservation. Cham, Switzerland: Springer. https://doi.org/10.1007/978-3-319-08096-3

New, T. R., A. L. Yen, D. P. A. Sands, P. Greenslade, P. J. Neville, A. York and N. G. Collett. 2010. Planned fires and invertebrate conservation in south east Australia. Journal of Insect Conservation 14(5): 567-574.

https://doi.org/10.1007/s10841-010-9284-4

Raven, R. J., and G. Wishart. 2006. The trapdoor spider Arbanitis L. Koch (Idiopidae: Mygalomorphae) in Australia. Memoirs of the Queensland Museum 51: 531-557.

Ray, E. J., and E. A. Bergey. 2015. After the burn: factors affecting land snail survival in post-prescribed-burn woodlands. Journal of Molluscan Studies 81(1): 44-50. https://doi.org/10.1093/mollus/eyu051

Reid, C. A. M. 2020. New South Wales distribution records of described dung beetle species in the Australian Museum (Coleoptera: Scarabaeidae: Scarabaeinae). figshare. Dataset. https://doi.org/10.6084/m9.figshare.13059005

Rix, M. G., and M. S. Harvey. 2011. Australian assassins, part I: a review of the assassin spiders (Araneae, Archaeidae) of mideastern Australia. ZooKeys 123: 1-100. https://doi.org/10.3897/zookeys.123.1448

Rix, M. G., R. J. Raven, B. Y. Main, S. E. Harrison, A. D. Austin, S. J. B. Cooper, and M. S. Harvey. 2017a. The Australasian spiny trapdoor spiders of the family Idiopidae (Mygalomorphae: Arbanitinae): a relimitation and revision at the generic level. Invertebrate Systematics 31(5): 566-634. https://doi.org/10.1071/IS16065

Sands, D. P. A. 2018. Important issues facing insect conservation in Australia: now and into the future. Austral Entomology 57(2): $150-172$.

https://doi.org/10.1111/aen.12342

Shea, M., D. J. Colgan, and J. Stanisic. 2012. Systematics of the landsnail genus Gyrocochlea and relatives (Mollusca: Charopidae). Zootaxa 3585: 1-109.

https://doi.org/10.11646/zoootaxa.3585.1.1
Shea, M., and F. Köhler. 2019. Towards a systematic revision of eastern Australian land snail Austrochloritis Pilsbry, 1891 (Eupulmonata, Camaenidae): redescription of its type species, A. porteri (Cox, 1866). Records of the Australian Museum 71(4): 111-120.

https://doi.org/10.3853/j.2201-4349.71.2019.1699

Smith, B. J. 1998. Family Rhytididae. In Mollusca: The Southern Synthesis. Fauna of Australia. Vol. 5B, ed. P. L. Beesley, G. J. B. Ross, and A. Wells, pp. 1091-1093. Melbourne: CSIRO Publishing.

Smith, B. J., and J. Stanisic. 1998. Pulmonata Introduction. In Mollusca: The Southern Synthesis. Fauna of Australia. Vol. 5B, ed. P. L. Beesley, G. J. B. Ross, and A. Wells, pp. 1037-1060. Melbourne: CSIRO Publishing.

Solem, A. 1978. Classification of the Land Mollusca. In Pulmonates. Vol. 2A, Systematics, Evolution and Ecology, ed. V. Fretter, and J. Peake, pp. 49-97. London: Academic Press.

Solem, A. 1998. Family Camaenidae. In Mollusca: The Southern Synthesis. Fauna of Australia. Vol. 5B, ed. P. L. Beesley, G. J. B. Ross, and A. Wells, pp. 1112-1113. Melbourne: CSIRO Publishing.

Stanisic, J. 1998. Family Charopidae. In Mollusca: The Southern Synthesis. Fauna of Australia. Vol. 5B, ed. P. L. Beesley, G. J. B. Ross, and A. Wells, pp. 1097-1099. Melbourne: CSIRO Publishing.

Stanisic, J., M. Shea, D. Potter, and O. Griffiths. 2010. Australian Land Snails. Vol 1. A Field Guide to Eastern Australian Species. Mauritius: Bioculture Press.

Taylor, G. S., M. F. Braby, M. L. Moir, M. S. Harvey, D. P. A. Sands, T. R. New, R. L. Kitching, P. B. McQuillan, K. Hogendoorn, R. V. Glatz, M. Andren, J. M. Cook, S. C. Henry, I. Valenzuela, and P. Weinstein. 2018. Strategic national approach for improving the conservation management of insects and allied invertebrates in Australia. Austral Entomology 57: 124-149.

https://doi.org/10.1111/aen.12343

Turner, J. 1984. Radiocarbon dating of wood and charcoal in an Australian forest ecosystem. Australian Forestry 47(2): 79-83. https://doi.org/10.1080/00049158.1984.10675982

Van De Wal, C. 2020. Utilising total-evidence approaches to investigate crustacean evolution. Unpublished Ph.D. thesis. School of Life and Environmental Sciences, The University of Sydney, $222 \mathrm{pp}$.

Ward, M., A. I. T. Tulloch, J. Q. Radford, B. A. Williams, A. E. Reside, S. L. Macdonald, H. J. Mayfield, M. Maron, H. P. Possingham, S. J. Vine, J. L. O'Connor, E. J. Massingham, A. C. Greenville, J. C. Z. Woinarski, S. T. Garnett, M. Lintermans, B. C. Scheele, J. Carwardine, D. G. Nimmo, D. B. Lindenmayer, R. M. Kooyman, J. S. Simmonds, L. J. Sonter, and J. E. M. Watson. 2020. Impact of 2019-2020 mega-fires on Australian fauna habitat. Nature Ecology and Evolution 4: 1321-1326. https://doi.org/10.1038/s41559-020-1251-1

Wishart, G., and D. M. Rowell. 2008. Trapdoor spiders of the genus Misgolas (Mygalomorphae: Idiopidae) from eastern New South Wales, with notes on genetic variation. Records of the Australian Museum 60(1): 45-86.

https://doi.org/10.3853/j.0067-1975.60.2008.1495 